\title{
Mycelium growth and yield of wild strains of Pleurotus ostreatus (Jacq.:Fr.) Quel. cultivated on waste materials from the textile industry
}

\author{
Krzysztof Sobieralski ${ }^{1}$, Marek Siwulski, Iwona Sas-Golak', \\ Jerzy Mańkowski², Teresa Kotlińska ${ }^{3}$ \\ ${ }^{1}$ Department of Vegetable Crops \\ Poznan University of Life Sciences \\ Dąbrowskiego 159, 60-594 Poznań, Poland \\ ${ }^{2}$ Institute of Natural Fibres and Medicinal Plants \\ Wojska Polskiego 71b, 60- 630 Poznań, Poland \\ ${ }^{3}$ Laboratory of Plant Genetic Resources, Research Institute of Vegetable Crops \\ Konstytucji 3 Maja 1/3, 96-100 Skierniewice, Poland \\ e-mail: sobieralski@up.poznan.pl
}

\begin{abstract}
The objective of the experiment was to compare mycelium growth and the yield of wild strains of Pleurotus ostreatus derived from natural sites and of a cultivated HK35 strain. Mycelium growth was investigated on substrates prepared from the sawdust of deciduous trees, wheat and rye straw as well as by-products from the textile industry: flax and hemp shives. Irrespective of the applied substrate, the cultivated HK35 strain was characterised by the fastest growth, whereas amongst the examined wild strains, mycelia designated as U18/5, S12/3 and B17/4 were found to grow best. Substrates prepared from wheat and rye straw and flax shives turned out to be the best for mycelium growth of the tested strains of $P$. ostreatus. The yield of oyster mushroom depended on the type of applied substrate. Higher yields were recorded on substrates from flax shives and a mixture of wheat straw and hemp shives than on wheat straw. The cultivated HK35 strain and the wild S12/3 strain gave the highest yields irrespective of the kind of substrate.
\end{abstract}

Key words: flax shive, hemp shive, oyster mushroom, sawdust, straw, substrate

\section{INTRODUCTION}

Mushrooms from the Pleurotus sp. genus can be cultivated on different substrates, such as wheat, rye and rice straw or maize stalks (Stamets 2000), and there are many substrates used in the intensive cultivation of oyster mushroom. According to Poppe (2004), there are over 90 potential substrates, primarily agricultural wastes, which can be utilised as substrates for the cultivation of mushrooms from the Pleurotus genus. Thanks to ligninolytic, xylanolytic and cellulolytic enzymes, mushrooms from the Pleurotus sp. genus can be utilised for the delignification of waste materials developed in the course of agricultural production (Cohen et al. 2002). The usefulness of various celluloseand lignin-containing materials for mushroom cultivation was confirmed by the research results of a number of researchers (Zervakis et al. 2001, Ozcelik and Peksen 2007, Rani et al. 2008, Akeviae et al. 2009, Dundar et al. 2009). The aim of this experiment was to assess mycelium growth and the development of wild strains of $P$. ostreatus on substrates from flax and hemp shives and compare the obtained results with the mycelium growth of 
the above-mentioned strains on substrates from deciduous tree sawdust as well as wheat and rye straw commonly employed in the commercial cultivation of the oyster mushroom in our country.

\section{MATERIAL AND METHODS}

Investigations were carried out at the Department of Vegetable Crops of the Poznan University of Life Sciences in 2009. The examined wild $P$. ostreatus strains were derived from the collection of cultivated and medicinal mushrooms of the Department of Vegetable Crops of the Poznan University of Life Sciences and were obtained by workers of the Independent Workshop of Cultivated Mushrooms of the Research Institute of Vegetable Crops in Skierniewice from natural sites of various regions in Poland (Tab. 1).

Two independent experiments were performed; one was carried out in a laboratory and the other was a cultivation trial. In the course of the laboratory experiments, we examined the mycelium growth of all $P$. ostreatus strains given in Table 1 grown on substrates prepared from rye and wheat straw, beech, oak and poplar sawdust, as well as hemp and flax shives. The experiments were conducted in glass test tubes measuring $4 \mathrm{~cm}$ wide and $16 \mathrm{~cm}$ long. Incubation was conducted at a temperature of $25^{\circ} \mathrm{C}$ and the measure of growth was the thickness of the substrate layer overgrown by the mycelium after 10 days of incubation. In the cultivation trial, yields of the tested P. ostreatus HK35, B17/4, S12/3 and 418/5 strains growing on substrates prepared from wheat straw, flax shives as well as a mixture of wheat straw and hemp shives ( $4: 1$ by weight) were compared. The cultivation was conducted using plastic foil bags of $5 \mathrm{dm}^{3}$ volume, which were filled with the appropriate sterilised substrate of $65 \%$ moisture content and inoculated with mycelium. Incubation and cultivation were carried out in accordance with the requirements for $P$. ostreatus. The yield was evaluated on the basis of the harvest obtained from the first flush. A detailed description of the method employed in both experiments can be found in the paper by Siwulski et al. (2010 a).

The trial was established in four replications in a random design in the case of the laboratory experiment, and three replications in the cultivation experiment. The obtained research results were subjected to the analysis of variance for twofactorial experiments using the Duncan test at $p$ $=0.05$. The results were described as average values of the two series in the laboratory experiment and two cycles in the cultivation experiment.

\section{RESULTS AND DISCUSSION}

Wild strains of $P$. ostreatus as well as the HK35 cultivation strain differed with regard to the mycelium growth on the examined substrates. Mycelium of the HK35 strain was characterised by the best growth and the remaining wild strains exhibited a significantly poorer growth in comparison with the cultivated strain. From

Table 1. List of collected specimens of Pleurotus ostreatus

\begin{tabular}{|c|c|c|c|c|}
\hline No & Collection date & Location of collection site & Collection site & $\begin{array}{l}\text { Symbol } \\
\text { of strain }\end{array}$ \\
\hline 1. & XII-I & $\begin{array}{l}\text { Białystok Regional Directorate, Borki } \\
\text { Forest District }\end{array}$ & trunks of birch & $\mathrm{B} 17 / 4$ \\
\hline 2. & XII-I & Białowieża Forest District & lime trees & B19/1 \\
\hline 3. & I-III & $\begin{array}{l}\text { Szczecinek Regional Directorate; } \\
\text { Drawsko Forest District, Czertyń Sub- } \\
\text { district }\end{array}$ & beech trees & D7/24 \\
\hline 4. & I-III & $\begin{array}{l}\text { Szczecinek Regional Directorate; } \\
\text { Świerczyna Forest District, Buczyna } \\
\text { Sub-district }\end{array}$ & on beech trees & $\mathrm{S} 12 / 3$ \\
\hline 5. & I-III & $\begin{array}{l}\text { Szczecinek Regional Directorate; Ustka } \\
\text { Forest District, Sycewice Sub-district }\end{array}$ & beech trees & $\mathrm{U} 18 / 5$ \\
\hline 6. & XII-I & $\begin{array}{l}\text { Łódź Regional Directorate; Skierniewice } \\
\text { Forest District }\end{array}$ & Aesculus hipocastaneum & $\mathrm{S} 32 / 9$ \\
\hline 7. & I-III & $\begin{array}{l}\text { Katowice Regional Directorate; Kup } \\
\text { Forest District; Winna Góra Sub-district }\end{array}$ & beech trees & $\mathrm{W} 41 / 5$ \\
\hline 8. & XII-I & $\begin{array}{l}\text { Poznań Regional Directorate; Miranowo } \\
\text { Forest District, Piaski Sub-district }\end{array}$ & beech trees & $\mathrm{P} 33 / 4$ \\
\hline 9. & \multicolumn{3}{|c|}{$\begin{array}{l}\text { Pleurotus ostreatus strain HK } 35 \text { from the collection of cultivated and medicinal mushrooms } \\
\text { of the Department of Vegetable Crops of the Poznan University of Life Sciences }\end{array}$} & HK35 \\
\hline
\end{tabular}




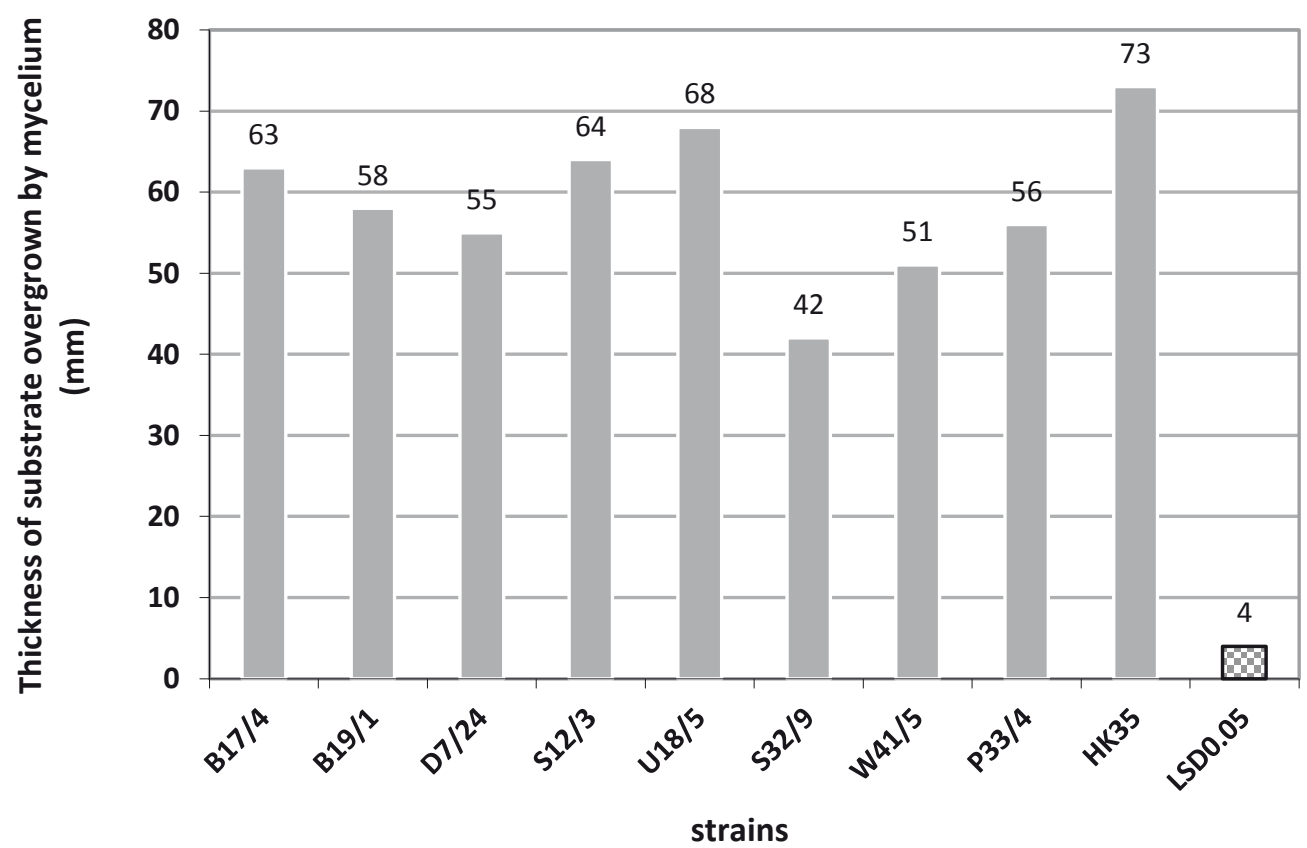

Figure 1. Mycelium growth of Pleurotus ostreatus strains on tested substrates

amongst the examined wild strains, U18/5 was characterised by the best mycelium growth. In comparison with this strain, significantly slower mycelium growth was recorded in the case of the S12/3 and B17/4 strains, followed by the B19/1, $\mathrm{D} 7 / 24$ and P33/4 strains. The mycelium of the W41/5 strain was characterised by an even worse growth, and strain S32/9 was found to exhibit the worst mycelium growth (Fig. 1).

The best mycelium growth of the examined $P$. ostreatus strains was determined on the substrates from wheat and rye straw and flax shives and then from poplar sawdust. A significantly worse mycelium growth was observed in the case of substrates from birch and oak sawdust. The poorest mycelium growth of the examined strains was determined on the substrate from hemp shives (Tab. 2).

The observed interaction between the kind of substrate and the examined $P$. ostreatus strains was significant. The substrate from flax shives was overgrown fastest by the B17/4, B19/1, U18/5, $\mathrm{S} 32 / 1, \mathrm{~W} 41 / 5$ and $\mathrm{P} 33 / 4$ as well as HK35 strain mycelium, whereas the S12/3, U18/5, P33/4 and B17/4, B19/1 as well as HK35 strains grew fastest on the substrate prepared from rye straw. Wheat straw was the best substrate for the cultivated HK35 strain as well as for the S12/3, U18/5, D7/24 and P33/4 strains (Tab. 2). The substrate from poplar sawdust was overgrown fastest by the B17/4, D7/24, $\mathrm{S} 12 / 3$ and U18/5 strain mycelium. Substrates

Table 2. Mycelium growth of Pleurotus ostreatus strains on different substrates (mm)

\begin{tabular}{|c|c|c|c|c|c|c|c|}
\hline \multirow{2}{*}{$\begin{array}{l}\text { Symbol } \\
\text { of strain }\end{array}$} & \multicolumn{7}{|c|}{ Substrates } \\
\hline & rye straw & wheat straw & $\begin{array}{c}\text { birch } \\
\text { sawdust }\end{array}$ & oak sawdust & $\begin{array}{c}\text { poplar } \\
\text { sawdust }\end{array}$ & hemp shive & flax shive \\
\hline B17/4 & 73 & 66 & 60 & 53 & 70 & 46 & 75 \\
\hline B19/1 & 62 & 60 & 58 & 50 & 56 & 50 & 68 \\
\hline D7/24 & 54 & 67 & 56 & 46 & 62 & 41 & 60 \\
\hline $\mathrm{S} 12 / 3$ & 75 & 74 & 59 & 51 & 70 & 47 & 70 \\
\hline U18/5 & 76 & 72 & 70 & 65 & 70 & 45 & 75 \\
\hline $\mathrm{S} 32 / 9$ & 47 & 53 & 40 & 33 & 45 & 30 & 46 \\
\hline W41/5 & 55 & 59 & 47 & 40 & 53 & 44 & 60 \\
\hline P33/4 & 69 & 61 & 53 & 47 & 58 & 43 & 64 \\
\hline HK35 & 78 & 81 & 72 & 68 & 75 & 58 & 77 \\
\hline Mean & 65 & 66 & 57 & 50 & 62 & 45 & 66 \\
\hline
\end{tabular}

$\mathrm{LSD}_{0.05}$ for substrates $=4$

$\operatorname{LSD}_{0.05}$ for interaction $=7$

Effect of strain $=$ non-significant differences 


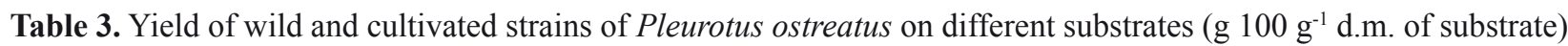

\begin{tabular}{lcccc}
\hline \multirow{2}{*}{ Strain } & \multicolumn{4}{c}{ Substrate } \\
\cline { 2 - 5 } & wheat straw & flax shive & wheat straw + hemp shive & Mean \\
\hline B17/4 & 53 & 60 & 59 & 57 \\
\hline S12/3 & 60 & 68 & 68 & 65 \\
\hline $418 / 5$ & 41 & 54 & 58 & 51 \\
\hline HK35 & 62 & 71 & 69 & 67 \\
\hline Mean & 54 & 63 & 64 & - \\
\hline
\end{tabular}

$\mathrm{LSD}_{0.05}$ for strains $=5$

$\operatorname{LSD}_{0.05}$ for substrates $=6$

$\operatorname{LSD}_{0.05}^{0.05}$ for interaction $=8$

prepared from oak and birch sawdust and hemp shives exhibited the slowest rate of overgrowing by mycelium of the examined $P$. ostreatus strains.

The presented results corroborated research results obtained earlier by Siwulski et al. (2010 b). The above-mentioned researchers demonstrated that the response of some mushroom species to the kind of substrate differed strongly. Mycelia of Ganoderma lucidum, Hericium erinaceus and Lentinula edodes grew better on sawdust substrate than on flax and hemp shives and straw, whereas the mycelium of such species as Agrocybe aegerita, Pholiota nameko and Flammulina velutipes showed the best growth on substrate prepared from flax shives. Zervakis et al. (2001) reported a very good growth of Pleurotus sp. mycelium on substrate from cotton waste.

Mycelia of the wild strains as well as of the cultivated $P$. ostreatus strain used in the experiments exhibited very good growth on substrates prepared from flax shives, which was similar to growth achieved on the substrates most frequently employed in commercial cultivation, i.e. from rye and wheat straw. It is also worth emphasising that the mycelium growth of the examined $P$. ostreatus strains was very slow on the substrate from hemp shives and was similar to their growth on the oak sawdust substrate.

The yield of $P$. ostreatus depended on the kind of substrate. Curvetto et al. (2002) and Obodai et al. (2003) reported differences in yields between $P$. ostreatus strains growing on different substrates. In their earlier experiments, the authors of this article reported the suitability of flax and hemp shives for the cultivation of two strains of oyster mushroom: K22 and P80 (Siwulski et al. 2010 b). Higher yields were obtained on substrates prepared from flax shives and a mixture of wheat straw and hemp shives in comparison with the yield obtained from the cultivation on wheat straw. The response of all of the examined strains to the kind of the substrate was similar. $P$. ostreatus strains differed amongst one another with respect to the level of yields. The highest yields, irrespective of the kind of applied substrate, were recorded for the cultivated strain HK 35 and the wild S12/3 strain. Lower yields were recorded in the case of the B17/4 strain and the 418/5 strain had the lowest (Tab. 3).

\section{CONCLUSIONS}

1. The kind of applied substrate affected mycelium growth and yield of the examined $P$. ostreatus strains. The best substrates for $P$. ostreatus mycelium growth included wheat and rye straw and flax shives. The most suitable substrate for cultivation from the point of view of the obtained yields was a mixture of wheat straw and hemp shives.

2. The responses of the examined $P$. ostreatus strains to the kind of substrate with regard to the examined traits were similar.

\section{REFERENCES}

Akeviae., Beharav A., Wasser S.P., Nevo E., 2009. Disposal of agro-industrial by-products by organic cultivation of culinary and medicinal mushroom Hypsizygus marmoreus. Waste Manag. 29/5: 16221627.

Cohen R., Persky L., Hadar Y., 2002. Biotechnological applications on potential of wood degrading mushrooms of the genus Pleurotus. Appl. Microbiol. Biotechnol. 58: 582-594.

Curvetto N., Figla D., Devalis R., Delmastro S., 2002. Growth and productivity of different Pleurotus ostreatus strains on sunflower seed hulls

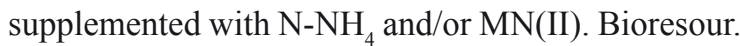
Technol. 84: 171-176.

Dundar A., Acay H., Yildiz A., 2009. Effect of using different lignocellulosic wastes for cultivation of Pleurotus ostreatus (Jacq.) P. Kumm. on mushroom 
yield, chemical composition and nutritional value. African J. Biotechnol. 8/4: 662-666.

Obodai M., Cleland-Okine J., Vowotor K.A., 2003. Comparative study of the growth and yield of $P$. ostreatus on different lignocellulosic by-products. J. Ind. Microbial. Biotechnol. 30: 146-149.

Ozcelik E., Peksen A., 2007. Hazelnut husk as a substrate for the cultivation of shiitake mushroom (Lentinula edodes). Bioresource Technol. 98/14: 2652-2658.

Poppe J., 2004. Agricultural wastes as substrates for oyster mushroom. In: Mushroom Growers Handbook. MushWorld Publ.: 75-85.

Rani P., Kalyani N., Prathiba K., 2008. Evaluation of lignocellulosic wastes for production of edible mushrooms. Appl. Biochem. Biotechnol. 151(2-3): 151-159.

Siwulski M., Drzewiecka K., Sobieralski K., Chong Y., 2010 a. Comparison of growth and enzymatic activity of mycelium and yielding of Pleurotus ostreatus (Fr.) Kumm on different substrates. Acta Sci. Pol., Hortorum Cultus 9(3): 45-50.

Siwulski M., Sobieralski K., Mańkowski J., 2010 b. Comparison of mycelium growth of selected species of cultivated mushrooms on textile industry waste. Acta Sci. Pol., Hortorum Cultus 9(3): 37-43.

StAmets P., 2000. Growing gourmet and medicinal mushrooms. Ten Speed Press, Berkeley, Toronto, $574 \mathrm{p}$.

Zervakis G., Philippoussis A., IoAnnidou S., Diamantopoulou P., 2001. Mycelium growth kinetics and optimal temperature conditions for cultivation of edible mushroom species on lignocellulosic substrates. Folia Microbiol. 46/3: 231-234.

\section{WZROST GRZYBNI I PLONOWANIE DZIKICH RAS BOCZNIAKA OSTRYGOWATEGO PLEUROTUS OSTREATUS (JACQ.:FR) QUEL. NA MATERIAŁACH ODPADOWYCH PRZEMYSŁU WŁÓKIENNICZEGO}

Streszczenie: W doświadczeniu porównano wzrost grzybni dzikich ras boczniaka ostrygowatego Pleurotus ostreatus pochodzących ze środowiska naturalnego oraz rasy uprawnej HK 35. Wzrost grzybni badano na podłożach $\mathrm{z}$ trocin drzew liściastych, a także słomie pszennej i żytniej oraz odpadach przemysłu włókienniczego: paździerzach lnianych i konopnych. Najszybszym wzrostem, niezależnie od zastosowanego podłoża, cechowała się rasa uprawna HK35, a wśród badanych dzikich ras najlepiej rosła grzybnia oznaczona jako U18/5, S12/3 i B17/4. Najlepszymi podłożami dla wzrostu badanych ras boczniaka okazały się słoma pszenna i żytnia oraz paździerze lniane. Plon boczniaka zależał od rodzaju podłoża. Większy plon uzyskano na podłożu z paździerzy lnianych i mieszaniny słomy pszennej z paździerzami konopnymi niż na słomie pszennej. Niezależnie od rodzaju podłoża, największy plon dała rasa uprawna HK35 i dzika rasa $\mathrm{S} 12 / 3$.

Received November 10, 2010; accepted November 7, 2011 